J. Clin. Chem. Clin. Biochem.

Vol. 23, 1985, pp. $781-785$

\title{
Evaluation of a Fully Mechanized Enzymatic Kinetic Determination of Sialic Acid
}

\author{
By $A . M$. Gressner and K. H. Henn \\ Abteilung für Klinische Chemie und Zentrallaboratorium, Klinikum der Philipps-Universität Marburg
}

(Received March 26/July 19, 1985)

Summary: The enzymatic determination of sialic acid, commercially introduced recently as an end point method, has been considerably improved by the development of initial rate and peak rate modifications of the kinetic method, respectively, and adapted to a centrifugal analyser (Cobas Bio). The assay is completed within $3 \mathrm{~min}$, takes $3 \mu \mathrm{l}$ sample volume and is reduced to a total reaction volume of $153 \mu \mathrm{l}$. The costs per test thereby are lowered to about $10 \%$ of the original procedure. Within-run and day-to-day imprecisions $(\overline{\mathrm{x}}=0.81 \mathrm{~g} / \mathrm{l})$ are $2 \%$ and $3.9 \%$, respectively; inaccuracy is between $+1 \%$ and $-2 \%$. The detection limit is $0.012 \mathrm{~g} / \mathrm{l}$, i. e. about 3 times higher than that of the thiobarbituric acid method $(0.0037 \mathrm{~g} / \mathrm{l})$ for sialic acid determination. The enzymatic-kinetic assay correlates well with the latter method $(r=0.973)$. There was no measurable interference by EDTA $(<3 \mathrm{mg} / \mathrm{l})$, bilirubin $(<160 \mu \mathrm{mol} / \mathrm{l})$, haemolysis (haemoglobin $<5.25$ $\mathrm{g} / \mathrm{l})$, or triglycerides $(<3.50 \mathrm{~g} / \mathrm{l})$. The reference range (2.5th to 97.5 th percentile) for sialic acid in sera of adults is 0.51 to $0.84 \mathrm{~g} / 1$ (median $0.63 \mathrm{~g} / \mathrm{l}$ ) with no significant sex-related differences. The reference range for sialic acid in spontaneous urine samples is $0.01-0.13 \mathrm{~g} / \mathrm{l}$.

\section{Evaluierung einer voll mechanisierten enzymatisch-kinetischen Methode der Sialinsäurebestimmung}

Zusammenfassung: Eine kürzlich kommerziell eingeführte enzymatische Endpunktbestimmung der Sialinsäure wurde deutlich verbessert durch Entwicklung von initial rate und peak rate Modifikationen der kinetischen Bestimmung, die an einen Zentrifugalanalysator (Cobas Bio) adaptiert wurden. Die Bestimmung ist innerhalb von 3 Minuten beendigt, benötigt ein Probevolumen von $3 \mu$ l und ist auf ein Gesamtvolumen von $153 \mu \mathrm{l}$ reduziert worden. Dadurch wurden die Kosten pro Test auf etwa 10\% der ursprünglichen Kosten gesenkt. Die intraserielle und interserielle Unpräzision $(\overline{\mathrm{x}}=0,81 \mathrm{~g} / \mathrm{l})$ ist $2 \%$ bzw. $3,9 \%$, die Unrichtigkeit bewegt sich zwischen $+1 \%$ und $-2 \%$. Die Nachweisgrenze wurde mit $0,012 \mathrm{~g} / 1$ bestimmt und ist somit etwa 3fach höher als die der Thiobarbitursäure-Methode $(0,0037 \mathrm{~g} / \mathrm{l})$ der Sialinsäurebestimmung. Die enzymatisch-kinetische Methode korreliert gut mit der Thiobarbitursäure-Methode $(r=0,973)$. EDTA $(<3$ $\mathrm{mg} / \mathrm{l})$, Bilirubin $(<160 \mu$ mọl/l), Hämolyse (Hämoglobin $<5,25 \mathrm{~g} / \mathrm{l})$ und Triglyceride $(<3,50 \mathrm{~g} / \mathrm{l})$ sind keine Störfaktoren der enzymatischen Methode. Der Referenzbereich $(2,5$. $-97,5$. Perzentile) der Sialinsäurekonzentration in Sera von Erwachsenen liegt zwischen 0,51 und 0,84 g/l (Median 0,63 g/l) ohne geschlechtsabhängige Unterschiede zu zeigen. In Spontanurinproben beträgt der diesbezügliche Referenzbereich für Sialinsäure $0,01-0,13 \mathrm{~g} / \mathrm{l}$.

\section{Introduction}

Sialic acid ( $\mathrm{N}$-acetylneuraminic acid, NANA) is a main constituent of a large variety of glycoproteins and glycolipids, and as such it is present intracellularly, on the external cell surface and in various body fluids. Plasma glycoproteins bear sialic acid in the terminal position of the oligosaccharide chains, which has been shown to be crucial for their half life time in the circulation $(1,2)$. The level of protein- and lipid-bound sialic acid is regulated by the catalytic activities of sialyltransferase and neuraminidase, respectively. Apart from rare hereditary disorders of 
sialic acid metabolism (e. g. sialidosis) (3-5) a number of acquired diseases such as acute inflammatory processes and tumours are associated with elevated levels of sialic acid in serum and urine $(6-10)$. In fact, the determination of sialic acid in serum has been proposed as a useful cancer screen; serial determinations of sialic acid in patients with tumours might be a reliable marker of tumour activity, progression and/or metastasis (10-12). Chemical methods for the measurement of sialic acid like the thiobarbituric acid method (13), periodate resorcinol procedure (14), resorcinol-hydrochloric acid method (15), and the method using Ehrlich's reagent (10) are either time-consuming and laborious or unreliable due to non-specific colour interferences. Attempts have been made for automation of sialic acid measurements based on some of these reaction principles $(16,17)$. Recently, highly specific enzymatic assays of sialic acid applying neuraminidase and NANAaldolase have been developed and commercially introduced $(18 ;$ ' 19). In the present study we report a kinetic, fully mechanized modification of a commercially available test which enables fast, simple, precise, and relative inexpensive determinations of sialic acid in microvolumes of various body fluids and, thus, is suitable for routine laboratory use.

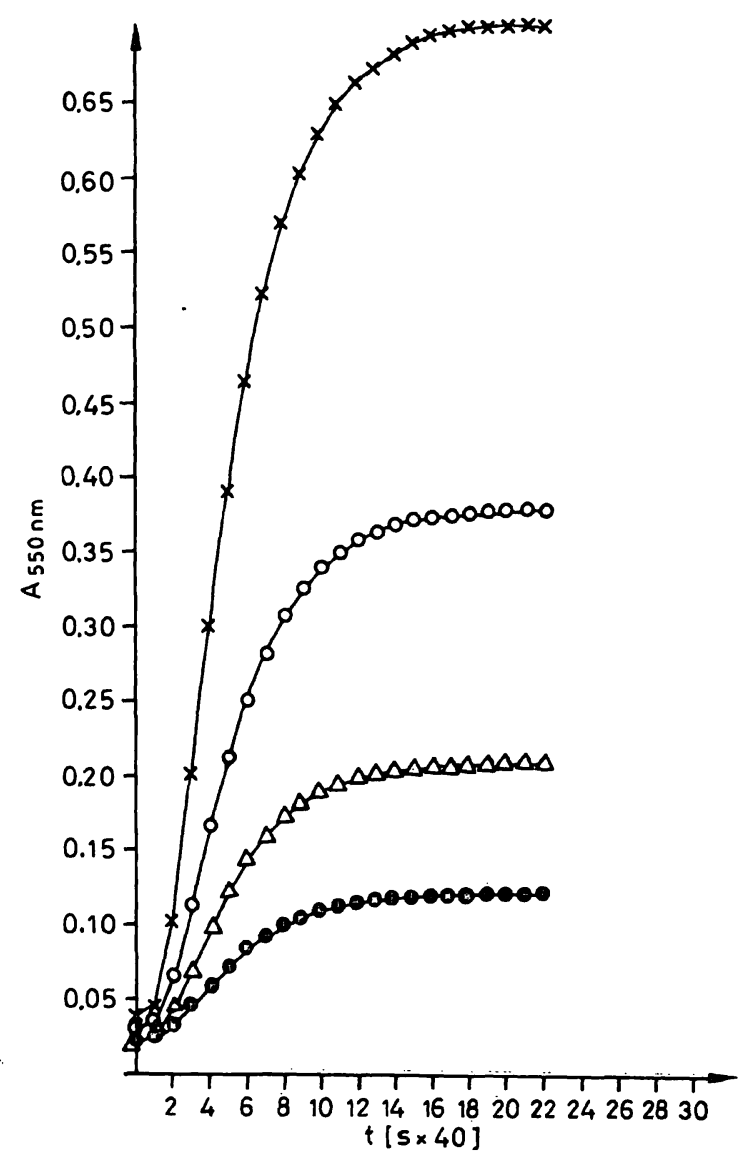

Fig. 1. Time-dependent change of absorbance at $550 \mathrm{~nm}$ in the enzymatic assay of sialic acid. $0-0.21 \mathrm{~g} / \mathrm{l}, \Delta-\Delta$ $0.42 \mathrm{~g} / \mathrm{l}, 0-00.84 \mathrm{~g} / \mathrm{l}, \mathrm{x}-\times 1.68 \mathrm{~g} / \mathrm{l}$.

\section{Materials and Methods}

Specimens

Sera, urine, cerebrospinal fluid and ascites were obtained from the routine clinical-chemical analysis program of the central laboratory. Biochemically and clinically healthy blood donors ( 52 females, 74 males) ranging from 19 to 48 years served as the reference population. The specimens were stored for a maximum of one week at $-20^{\circ} \mathrm{C}$ before use.

\section{Enzymatic assay of sialic acid}

Sialic acid was determined by a modification of the enzymatic end point method introduced recently (Boehringer Mannheim $\mathrm{GmbH}, \mathrm{FRG}$ ). In principle, bound sialic acid is enzymatically (neuraminidase) liberated and cleaved by NANA aldolase into pyruvate and $\mathrm{N}$-acetylmannosamine. Pyruvate then is enzymatically oxidized, using pyruvate oxidase. The $\mathrm{H}_{2} \mathrm{O}_{2}$ formed reacts in the presence of peroxidase with 4-aminoantipyrine and $\mathrm{N}$ ethyl-N-2-hydroxyethyl-3-toluidine to yield a red dye of which the absorbance is measured at $550 \mathrm{~nm}$. In the original instruction the test is performed in a total volume of $3.02 \mathrm{ml}$ with a sample volume of $20 \mu$ during an incubation time of about 60 min and read against a reagent blank. Calculation is based on the parallel incubation of sialic acid standard solution. The test principle was modified in this study as will be described in results and adapted to the Cobas Bio centrifugal analyser (Hoffmann La Roche). Parameter listing of the Cobas Bio is as follows:

$\begin{array}{rlc}1 & \text { Units } & \ddot{\mathbf{g}} / \mathbf{l} \\ 2 & \text { Calculation factor } & 10.2 \\ 3 & \text { Standard 1 Conc } & 0 \\ 4 & \text { Standard 2 Conc } & 0 \\ 5 & \text { Standard 3 Cond } & 0 \\ 6 & \text { Limit } & 3 \\ 7 & \text { Temperature }\left({ }^{\circ} \mathrm{C}\right) & 37.0 \\ 8 & \text { Type of analysis } & 3 \\ 9 & \text { Wavelength }(\mathrm{nm}) & 550 \\ 10 & \text { Sample Volume }(\mu \mathrm{l}) & 03 \\ 11 & \text { Diluent Volume }(\mu \mathrm{l}) & 00 \\ 12 & \text { Reagent Volume }(\mu \mathrm{l}) & 75 \\ 13 & \text { Incubation Time }(\mathrm{s}) & 10 \\ 14 & \text { Start Reagent Völume }(\mathrm{l}) & 75 \\ 15 & \text { Time of first reading }(\mathrm{s}) & 60.0 \\ 16 & \text { Time interval }(\mathrm{s}) & 10 \\ 17 & \text { Number of readings } & 12 \\ 18 & \text { Blanking Mode } & 1 \\ 19 & \text { Printout Mode } & 1\end{array}$

Thiobarbituric acid assay of sialic acid

The original procedure of Warren was followed with only minor modifications (13). The test was performed manually, the absorbance was read at $549 \mathrm{~nm}$ using a Lambda UV/VIS spectrophotometer (Perkin-Ëlmer). The test was calibrated with a human serum pool of which the sialic concentration was determined enzymatically.

\section{Results}

\section{Time course of the reation}

After a lag phase of about $80 \mathrm{~s}$ the absorbance at $550 \mathrm{~nm}$ increases linearly up to $280 \mathrm{~s}$ (fig. 1). The endpoint of the reaction is reached between $9.3 \mathrm{~min}$ (at low concentrations) and $13.3 \mathrm{~min}$ (at high conceñ- trations) (fig. 1). The maximum change of absorbance per $40 \mathrm{~s}$ is achieved $2.7 \mathrm{~min}$ after starting the reaction 
(fig. 2). It is dependent on the concentration of sialic acid as documented in figure 3 . These kinetics allow both an initial rate and a peak rate calculation of the sialic acid concentration. The former takes $3 \mathrm{~min}$ and includes 12 measurements in $10 \mathrm{~s}$ intervals after a preincubation period of $1 \mathrm{~min}$. The peak rate modification needs about $2.7 \mathrm{~min}$. Thus, the peak rate method offers no advantages over the initial rate technique, which therefore was used in the following studies.

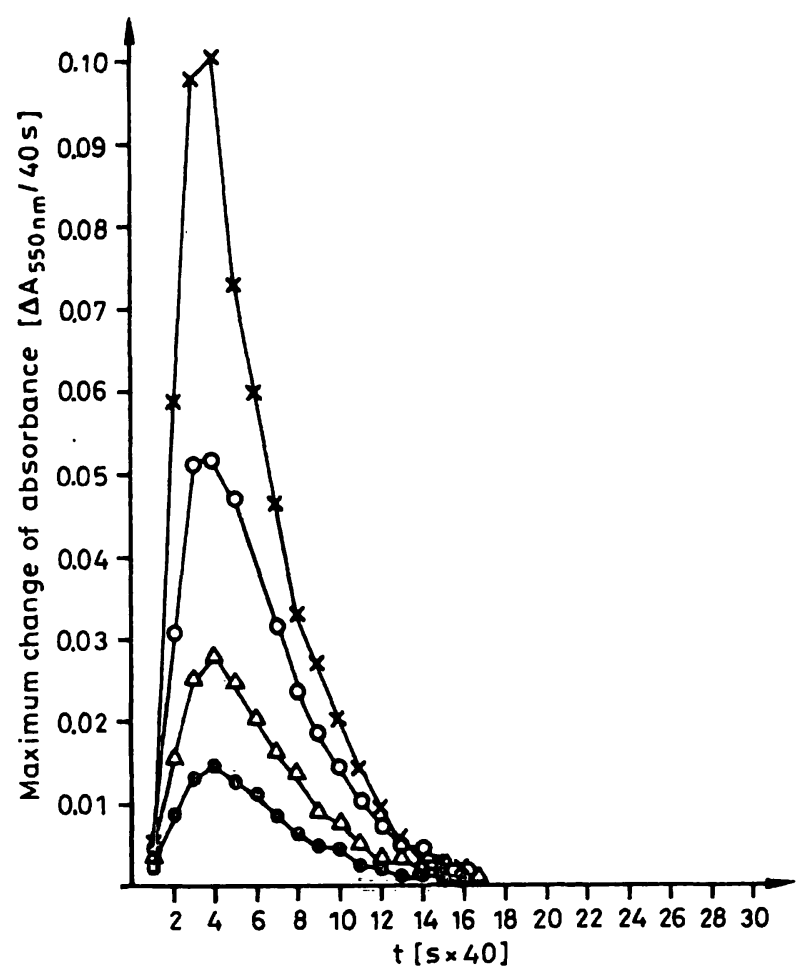

Fig. 2. Time course of the maximum change of absorbance in the enzymatic assay of sialic acid. Absorbance was measured at $40 \mathrm{~s}$ intervals. $-00.21 \mathrm{~g} / \mathrm{l} ; \Delta-\Delta 0.42$ $\mathrm{g} / 1 ; 0-00,84 \mathrm{~g} / 1 ; \mathrm{x}-\times 1.68 \mathrm{~g} / \mathrm{l}$.

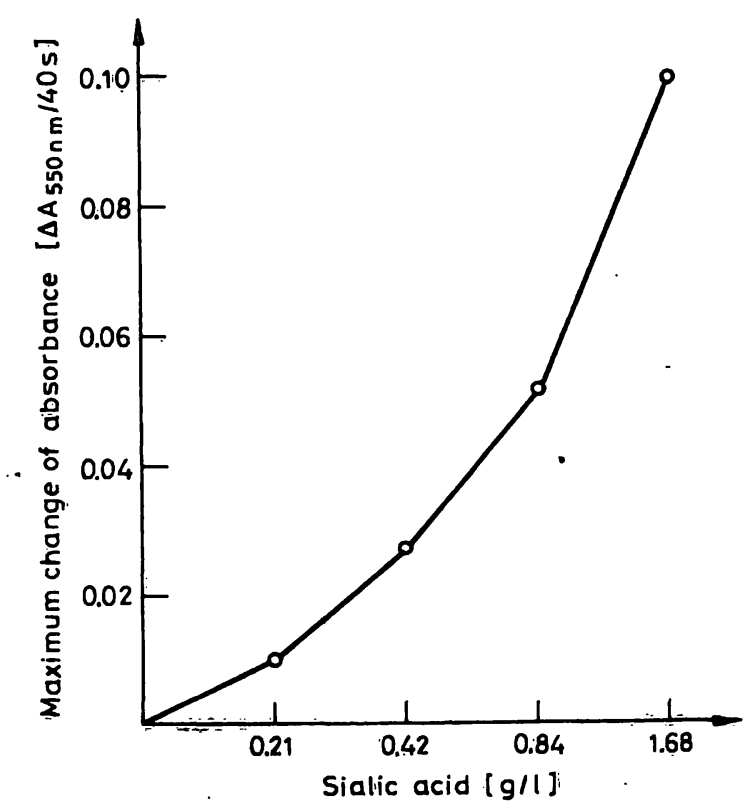

Fig. 3. Relation between the maximum change of absorbance and sialic acid concentration in the enzymatic assay. Absorbance was measured at $\mathbf{4 0} \mathrm{s}$ intervals.

\section{Imprecision and inaccuracy}

Within-run and day-to-day imprecisions at high and normal concentrations of sialic acid are summarized in table 1 and compared with the manual thiobarbituric acid procedure. As expected the analytical criteria of the mechanized enzymatic-kinetic assay are much superior to those of the Warren method. The inaccuracy of the enzymatic method tested at a sialic acid concentration of $0.84 \mathrm{~g} / \mathrm{l}$ was found to be between +1 and $-2 \%$.

Tab. 1. Within-run $(n=15)$ and day-to-day $(n=20) \mathrm{im}$ precision of the enzymatic-kinetic and the thiobarbituric acid method. Aliquots of pooled human sera were kept frozen at $-20^{\circ} \mathrm{C}$. The data are given for normal and for high concentrations of sialic acid in serum.

\begin{tabular}{llll}
\hline Assay procedure & $\begin{array}{l}\text { Sialic acid } \\
\overline{\mathrm{x}} \\
(\mathrm{g} / \mathrm{l})\end{array}$ & $\begin{array}{l}\mathrm{s} \\
(\mathrm{g} / \mathrm{l})\end{array}$ & $\begin{array}{l}\mathrm{CV} \\
(\%)\end{array}$ \\
& & & \\
& & & \\
Enzymatic-kinetic & 1.65 & 0.08 & 5.0 \\
within-run & 0.81 & 0.02 & 2.0 \\
& 0.84 & 0.03 & 3.9 \\
day-to-day & 0.42 & 0.02 & 5.5 \\
& & & \\
Thiobarbituric acid & 1.65 & 0.10 & 6.4 \\
within-run & 0.81 & 0.08 & 9.9 \\
& 0.83 & 0.10 & 12.7 \\
day-to-day & 0.39 & 0.06 & 16.3 \\
& & & \\
\hline
\end{tabular}

\section{Sensitivity and linearity}

The detection limit of the enzymatic assay is defined at a sialic acid concentration of $0.012 \mathrm{~g} / \mathrm{l}$ corresponding to $36 \mathrm{ng}$ in the assay, whereas that of the thiobarbituric acid method is $0.0037 \mathrm{~g} / \mathrm{l}$. Thus, the sensitivity of the latter method is about 3 times higher than that of the enzymatic procedure. The linearity of the enzymatic method was tested up to a sialic acid concentration of $3 \mathrm{~g} / \mathrm{l}$. Within the range between 3 and $0.012 \mathrm{~g} / \mathrm{l}$ the measured values were proportional to those expected from the sample dilutions.

\section{Interference and sample stability}

The enzymatic-kinetic assay of sialic acid did not show any interferences with EDTA up to $3 \mathrm{mg} / \mathrm{l}$, citrate up to $0.015 \mathrm{~mol} / \mathrm{l}$, bilirubin up to $160 \mu \mathrm{mol} / \mathrm{l}$, free haemoglobin up to $0.33 \mathrm{mmol} / \mathrm{l}$ and triglycerides up to $4.0 \mathrm{mmol} / \mathrm{l}$. Increasing concentrations of lipids caused erroneously high measurements of sialic acid concentration. Sample stability was tested for 3 weeks at storage temperatures of $-20^{\circ} \mathrm{C},+4^{\circ} \mathrm{C}$ and $+22^{\circ} \mathrm{C}$. During this period the concentration of sialic acid was found to be unchanged at any temperature. 
Comparison between the enzymatic-kinetic and the thiobarbituric acid method

The correlation between both methods was found to be satisfactory $(r=0.973, y=0.9845 x-0.0506)$. The concentrations of sialic acid ranging from 0.32 to $1: 40 \mathrm{~g} / \mathrm{l}$ determined in 63 unselected human sera were nearly identical (fig. 4).

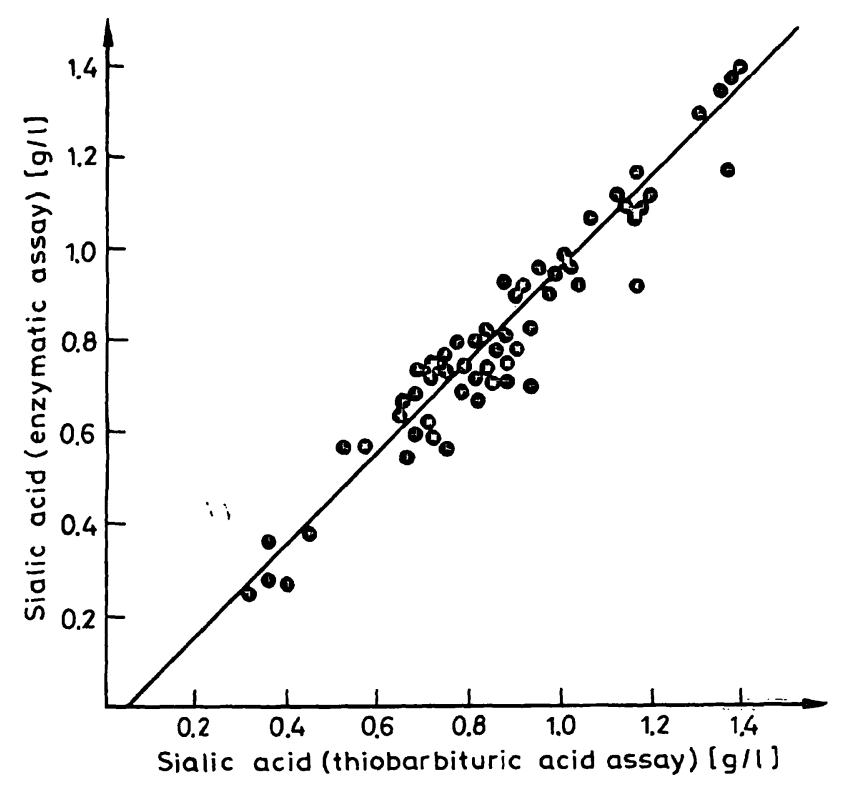

Fig. 4. Statistical correlation between the enzymatic-kinetic (y) and the thiobarbituric acid (x) method for determination of sialic acid in unselected human sera. $r=0.973$, $\mathrm{y}=0.9845 \mathrm{x}-0.0506, \mathrm{n}=63$.

\section{Reference values}

The reference ranges were determined in 74 male and 52 female healthy blood donors (ranging from 19 to 48 years) (tab. 2). The sialic acid concentration in males (median $0.63 \mathrm{~g} / \mathrm{l}$ ) and females (median $0.61 \mathrm{~g} / \mathrm{l}$ ) did not differ significantly.

Tab. 2. Reference ranges of sialic acid concentrations in serum.

\begin{tabular}{|c|c|c|c|c|c|}
\hline & \multicolumn{4}{|c|}{ Percentile } & \multirow[b]{2}{*}{ 97.5th } \\
\hline & $\begin{array}{l}\text { Median } \\
\text { sialic } \\
\text { acid } \\
(\mathrm{g} / \mathrm{l})\end{array}$ & sialic & acid $(g$ & 95th & \\
\hline Males $(n=74)$ & 0.63 & 0.51 & 0.52 & 0.76 & 0.79 \\
\hline Females $(\mathrm{n}=52)$ & 0.61 & 0.54 & 0.54 & 0.81 & 0.84 \\
\hline
\end{tabular}

Sialic acid determinations in other body fluids

The reference range (2.5th-97.5th percentile) of sialic acid concentration in spontaneous urine samples $(n=30)$ is $0: 01-0.13 \mathrm{~g} / \mathrm{l}$. In ascites from a patient with liver cirrhosis a sialic acid concentration of $0.06 \mathrm{~g} / \mathrm{l}$ was determined, whereas in ascites due to peritonitis carcinomatosa a substantial increase of sialic acid $(0.94 \mathrm{~g} / \mathrm{l})$ was measured. In cerebrospinal fluids $(\mathrm{n}=4)$ the concentrations ranged from $0.02 \mathrm{~g} / \mathrm{l}$ (normal composition) to $0.20 \mathrm{~g} / \mathrm{l}$ (bacterial meningitis with a greatly elevated total cell number and total protein concentration).

\section{Discussion}

The kinetic method of the enzymatic determination of sialic acid proves to be a rather simple, fast, precise, and relative inexpensive method for assaying the sugar in various body fluids. It avoids a reagent blank, is free of unspecific colour interferences and, as a further advantage, is suitable for mechanization as demonstrated in this communication by adaptation to the Cobas Bio centrifugal analyser. By these criteria the method is superior to those developed previously with a different reaction principle (10, $13-15)$. The determinations can be made in microvolumes of unextracted samples. The results of this method correlate well with those of the widely used Warren procedure (13). The sensitivity of the enzymatic method is lower than that of the thiobarbituric acid procedure (13) but still sufficient for most clinical purposes. Only $4 / 30$ of normal spontaneous urine samples have sialic acid concentrations hardly detectable by the enzymatic-kinetic method. Clinically relevant increases in the urinary output of sialic acid in cases of sialidosis $(3-5)$ can be monitored sensitively with the present method. The data for the reference range of sialic acid concentrations in urine are similar to those established recently with a comparable enzymatic method (19). Taken together the procedure described here will provide the analytic basis for large scale evaluation of the diagnostic and/ or prognostic potential of sialic acid in sera, urine and other body fluids of patients with cancer $(6-10)$, acute and chronic inflammatory processes $(6,10)$, and some inborn errors of sialic acid metabolism $(3-5,19,20)$.

\section{Acknowledgement}

We thank Mrs. Birgit Lahme for skilfull technical assistance. 


\section{References}

1. Ashwell, G. \& Harford, J. (1982) Ann. Rev. Biochem. 51, $531-554$.

2. Ashwell, G. \& Morell, A. G. (1974) Adv. Enzymol. 41, 99-128.

3. Lowden, J. A. \& O'Brien, J. S. (1979) Am. J. Hum. Genet. $31,1-18$.

4. Den Tandt, W. R. \& Leroy, J. G. (1980) Hum. Genet. 53, $383-388$.

5. Okada, S., Kato, T. \& Miura, S. (1978) Clin. Chim. Acta 86, $159-167$.

6. Silver, H. K., Karum, K. A., Archibald, E. L. \& Salinas, F. A. (1979) Cancer Res. 39, 5036-5042.

7. Silver, H. K. B., Rangel, D. M. \& Morton, D. L. (1978) Cancer 41, 1497-1499.

8. Carter, A. \& Martin, N. H. (1962) J. Clin. Pathol. 15, 69-72.

9. Mrochek, J. E., Dinsmore, S. R., Tormey, D. C. \& Waalkes, T. P. (1976) Clin. Chem. 22, 1516-1521.

10. Shamberger, R. J. (1984) J. Clin. Chem. Clin. Biochem. 22, $647-651$.
11. Kiricuta, O., Bojan, O., Comes, R. \& Christian, R. (1979) Arch. Geschwulstforsch. 49, 106-112.

12. Lipton, A., Harvey, H. A., Delong, S., Allegra, J., White, D., Allegra, M. \& Davidson, E. A. (1979) Cancer 43, 1766-1771.

13. Warren, L. (1959) J. Biol. Chem. 234, 1971-1975.

14. Jourdian, G. W., Deane, L. \& Roseman, S. (1971) J. Biol. Chem. 246, 430-435.

15. Svennerholm, L. (1957) Biochim. Biophys. Acta 24, 604-611.

16. Gerbaut, L., Rey, E. \& Lombaro, C. (1973) Clin. Chem. 19, $1285-1287$.

17. Rey, E., Gerbaut, C. \& Lombart C. (1975) Clin. Chem. 21, 412-414.

18. Boehringer Mannheim $\mathrm{GmbH}$, Testkombination Sialinsäure, Nr. 784192.

19. Okamura-Oho, Y., Yamanaka, T., Suzuki, Y., Akagi, M. \& Kobayashi, T. (1984) Clin. Chim. Acta 144, 263-267.

20. Palo, J., Rauvala, H., Finne, J., Haltia, M. \& Palmgren, K. (1985) Clin. Chim. Acta 145, 237-245.

Prof. Dr. A. M. Gressner

Abteilung für Klinische Chemie und

Zentrallaboratorium

Klinikum der Philipps-Universität

Baldingerstraße

D-3550 Marburg/Lahn 
